\title{
THE EFFECT OF ENVIRONMENTAL CONDITIONS AND BREEDER AGE ON EGG QUALITY CHARACTERISTICS
}

\author{
HEMIN, N. M. ${ }^{*}$-KHASRAW, A. A. \\ Department of Animal Sciences, College of Agricultural Sciences Engineering, University of \\ Sulaimani, Sulaymaniyah, Iraq \\ (e-mail:xasrao.ali@gmail.com) \\ *Corresponding author \\ e-mail: hemin.mohammed@univsul.edu.iq
}

(Received $10^{\text {th }}$ May 2019; accepted $16^{\text {th }} \mathrm{Jul} 2019$ )

\begin{abstract}
The study was carried out to investigate the effect of broiler breeder age (35 and 50 weeks), storage period ( 2 and 6 days) and storage type (cooling, $30^{\circ} \mathrm{C}$ hot room and partially oil covered in a hot room $30^{\circ} \mathrm{C}$ ) and their interactions on egg quality traits and hatchability of the Ross-308 broiler breeder eggs. The experiment included the measurements of the egg quality characteristics in the research laboratory. The results obtained from this experiment were summarized as the following: Broiler breeder ages had significant $(\mathrm{p} \leq 0.05)$ effects on some of the improved quality traits of the eggs such as: egg weight, albumin weight, yolk weight, haugh unit, yolk height, yolk index, hatchability and fertile egg hatchability percentage. Storage periods had significant $(\mathrm{p} \leq 0.05)$ effects on the egg weight, albumin weight, haugh unit, yolk index, hatchability and fertile egg hatchability percentage. Storage types (conditions) had significant ( $\mathrm{p} \leq 0.05$ ) effects on the egg weight, albumin weight, yolk weight, haugh unit, albumin and yolk percentage, albumin height, egg specific gravity and yolk height, yolk diameter, yolk index, hatchability and fertile egg hatchability percentage.
\end{abstract}

Keywords: egg quality, storage period, storage type, egg storage, hatchability

\section{Introduction}

Breeder age could be considered as one of the major factors affecting variability in egg characteristics, fertility, hatchability and broiler performance (Elibol et al., 2002; Guibert et al., 2012; Peebles et al., 2001). It is known that young breeders tend to have smaller eggs with higher proportion of albumen to yolk, lower albumen $\mathrm{pH}$ and higher shell thickness than eggs from old breeders (Peebles et al., 2000). Breeder age could be also a contributing factor to post- hatch performance of broilers, smaller yolk proportions of eggs from a young flock may be associated with low final body weight of their offspring (Ulmer-Franco et al., 2010). Hulet et al. (2007) reported that broilers from old breeders had higher body weight until $35 \mathrm{~d}$ compared to broilers from the young breeders. Generally, breeders kept in production till ages of 60-65 weeks. The main factors directly associated with egg deterioration are temperature and relative humidity, besides manipulation and storage period, however, during egg storage, some components of albumen and yolk may alter and tend to deteriorate egg quality (Feddern et al., 2017).

A storage duration beyond $7 \mathrm{~d}$ increases incubation duration (Tona et al., 2003) and has a negative effect on hatchability (Fasenko et al., 2001b; Tona et al., 2004; Yassin et al., 2008) and chick quality (Tona et al., 2003, 2004). The negative effects of prolonged egg storage may be caused by changes in egg characteristics, embryo quality or by both (Reijrink et al., 2008). Poor shell quality was associated with a higher percentage of egg moisture loss during incubation (Peebles et al., 2001) and low hatchability (Narushin and Romanov, 2002). It is suggested that prolonged egg storage may cause embryonic 
stress, manifesting in increasing embryonic necrotic and apoptotic cell death, decreased embryonic metabolism, and developmental delays; as a result, irreparable damage to the embryo may occur, thus resulting in increased embryonic mortality and decreased chick performance (Christensen et al., 2001; Fasenko, 2007; Hamidu et al., 2010).

Preincubation of hatching eggs before or during storage was reported to reduce the detrimental effects of periods of storage more than $7 \mathrm{~d}$ (Fasenko et al., 2001a; Reijrink et al., 2009). The effect of preincubation on hatchability was found to be influenced by the length of egg storage period and the developmental stage of the embryo before (Reijrink et al., 2009) or after (Fasenko et al., 2001a) the heating. According to Santos (2005), ambient temperature and prolonged egg storage negatively influenced the quality of eggs and significantly reduced the Haugh unit. Factors associated with the management and feeding of hens can play a role in internal egg quality, but egg handling and storage practices also had a significant impact on the quality of eggs reaching consumers (Jin et al., 2011).

The aim of this study was to investigate the effects of broiler breeder ages, egg storage periods and egg storage types on egg quality traits and hatching percentage.

\section{Materials and methods}

This study was conducted at the laboratory and poultry farm of College of Agricultural Sciences, University of Sulaimani, in Iraq. A total of (4200 eggs) of broiler breeder (Ross-308) were used in this experiment, at 35 and 50 weeks of breeder's age.

The experiment was divided in to two stages, the first stage included storing the eggs for 2 and 6 days in three types of storage conditions including (cooling, hot room $30^{\circ} \mathrm{C}$ and partially oil covered in hot room), followed by the second stage which started to measure the egg quality characteristics in the laboratory.

The experimental studied factors were as the following: Factor one: included two levels of broiler breeder ages (35 and 50) weeks. Factor two: included two levels of storage periods (2 and 6 days).

Factor three: included three levels of storage type (storing of the eggs in cooling, hot room at $30{ }^{\circ} \mathrm{C}$ and partially covered the eggs (blunt side) with oil in the hot room).

\section{Egg test}

Two thousand one hundred (2100) eggs were taken from each different breeder ages and 1050 eggs were stored for each 2 and 6 days in the three types of storage condition where 350 eggs selected for each type (storage types were denoted by cooling $=\mathrm{C}$, hot room $30^{\circ} \mathrm{C}=\mathrm{H}$ and partially oil covered in hot room $=\mathrm{O}$ ), after storage periods 50 eggs from each group were taken to measure the quality characteristic of the eggs and remain 300 eggs to for measure hatchability percentage.

\section{Egg weight (g)}

The eggs were weighed individually using sensitive electric balance type Mettler toledo $(\mathrm{max}=101 \mathrm{~g}$ and $\mathrm{e}=0.1 \mathrm{mg}$ ) and recorded in gram (Fig. 1).

\section{Albumin weight (g)}

After yolk separation from albumin, albumin was weighed by using sensitive electric balance type Mettler Toledo $(\max =101 \mathrm{~g}$ and $\mathrm{e}=0.1 \mathrm{mg})$ (Fig. 2). 


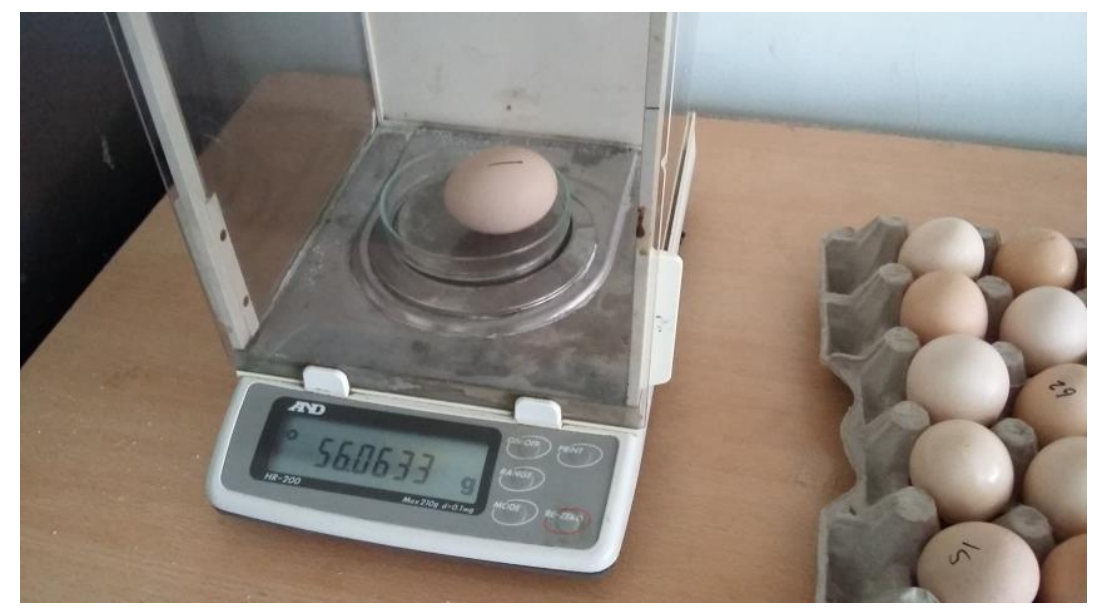

Figure 1. Sensitive electric balance type Mettler Toledo used to measure egg weight

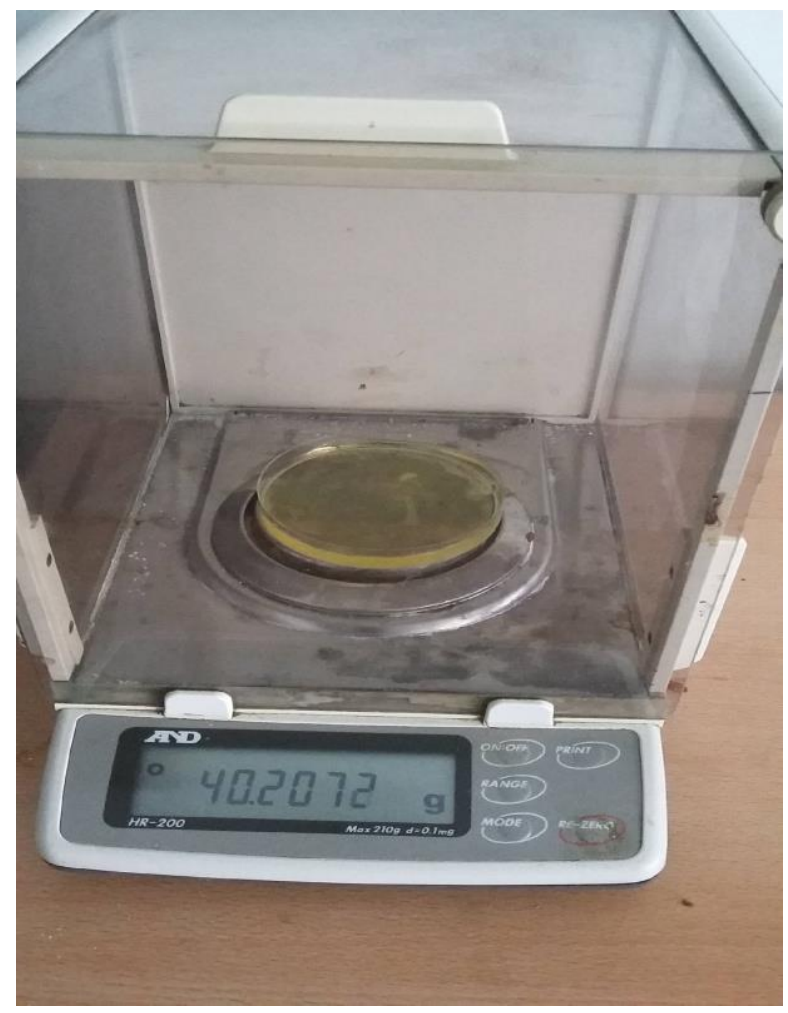

Figure 2. Sensitive electric balance type Mettler Toledo used to measure albumin weight

\section{Yolk weight (g)}

After yolk separation from albumin, yolk was weighed by the same balance (Fig. 3).

\section{Shell weight (g)}

Shell weight was calculated by the following equation:

Egg shell weight $=$ Egg weight $(g)-$ Yolk with albumin weight $(g)$ 


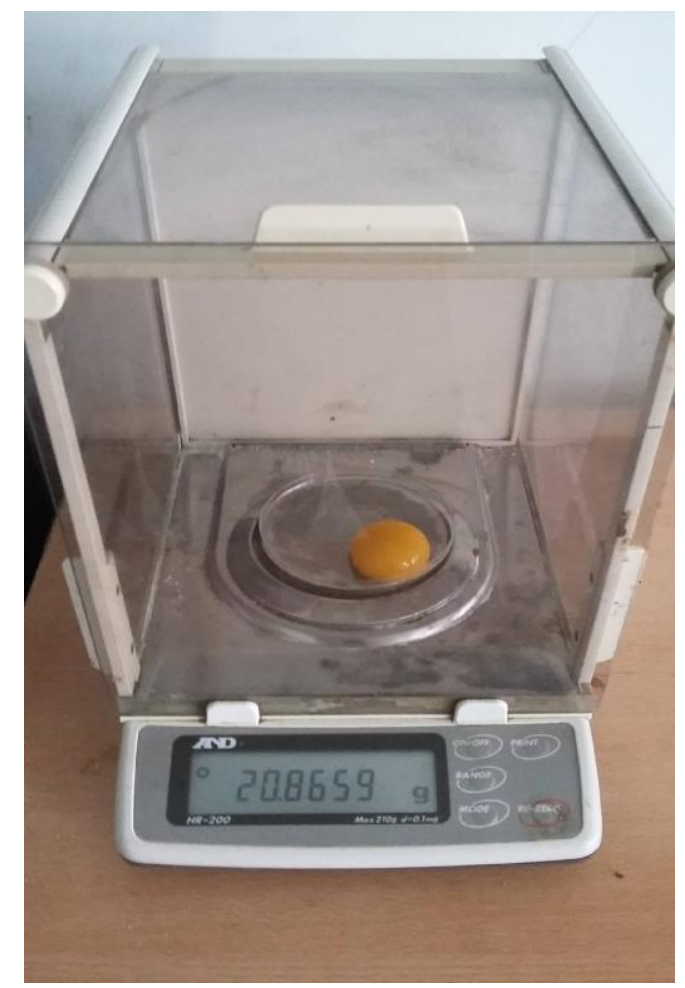

Figure 3. Sensitive electric balance type Mettler Toledo used to measure yolk weight

\section{Yolk, albumin and shell percentage}

Traits were calculated by the following equations:

$$
\begin{aligned}
\text { Yolk } \% & =\frac{\text { Yolk weight }(\mathrm{g})}{\text { Egg weight }(\mathrm{g})} \times 100 \\
\text { Albumin } \% & =\frac{\text { Albumin weight }(\mathrm{g})}{\text { Egg weight }(\mathrm{g})} \times 100 \\
\text { Shell } \% & =\frac{\text { Shell weight }(\mathrm{g})}{\text { Egg weight }(\mathrm{g})} \times 100
\end{aligned}
$$

\section{Yolk, albumin ratio}

The following equation was used to measure this trait:

$$
\text { Yolk, albumin ratio }=\frac{\text { Yolk weight }(\mathrm{g})}{\text { Albumin weight }(\mathrm{g})}
$$

\section{Albumin height (mm)}

Albumin height was recorded after pouring albumin on the phial-layer by Spherometer (Fig. 4). 


\section{Haugh unit (HU)}

Haugh unit was calculated depending on the albumin height $(\mathrm{mm})$ and egg weight $(\mathrm{g})$ by the following equation:

$$
\begin{gathered}
\mathrm{HU}=100\left[\log \left(\mathrm{H}+7.57-1.7 \mathrm{~W}^{0.37}\right)\right] \\
\mathrm{H}=\text { height of albumin }(\mathrm{mm}) \\
\mathrm{W}=\text { weight of egg }(\mathrm{g})
\end{gathered}
$$

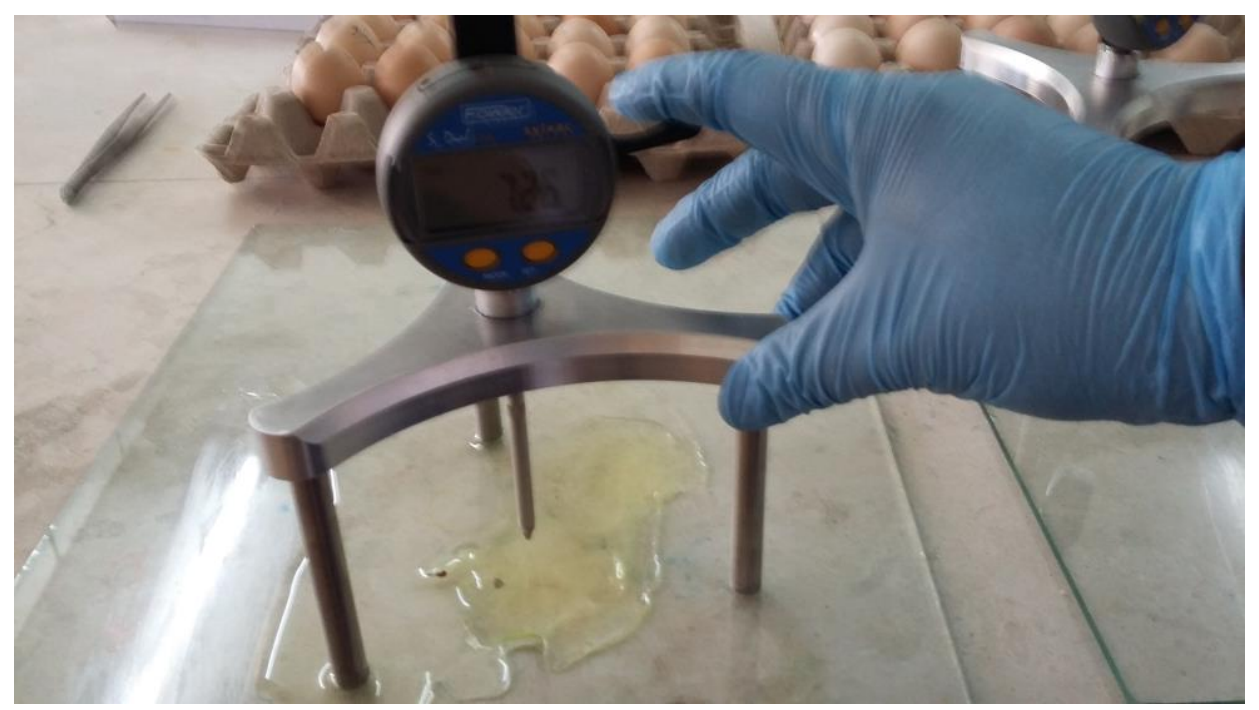

Figure 4. Spherometer used for measure albumin height

\section{Yolk height (mm)}

Yolk height was recorded by the Spherometer after pouring yolk in to the Petri-dish (Fig. 5).

\section{Yolk diameter ( $\mathrm{mm})$}

Yolk diameter was recorded by the same Vernier after pouring yolk in to the Petridish (Fig. 6).

\section{Yolk index}

Yolk index was calculated depending on the yolk height and yolk diameter ( $\mathrm{mm}$ ) by using this equation:

$$
\text { Yolk index }=\frac{\text { Yolk height }}{\text { Yolk diameter }}
$$

\section{Egg specific gravity}

Egg specific gravity was recorded after storing the eggs. Eggs were put-in the 9 of salt solution and egg specific gravity takes the same specific gravity of solution that float it. 


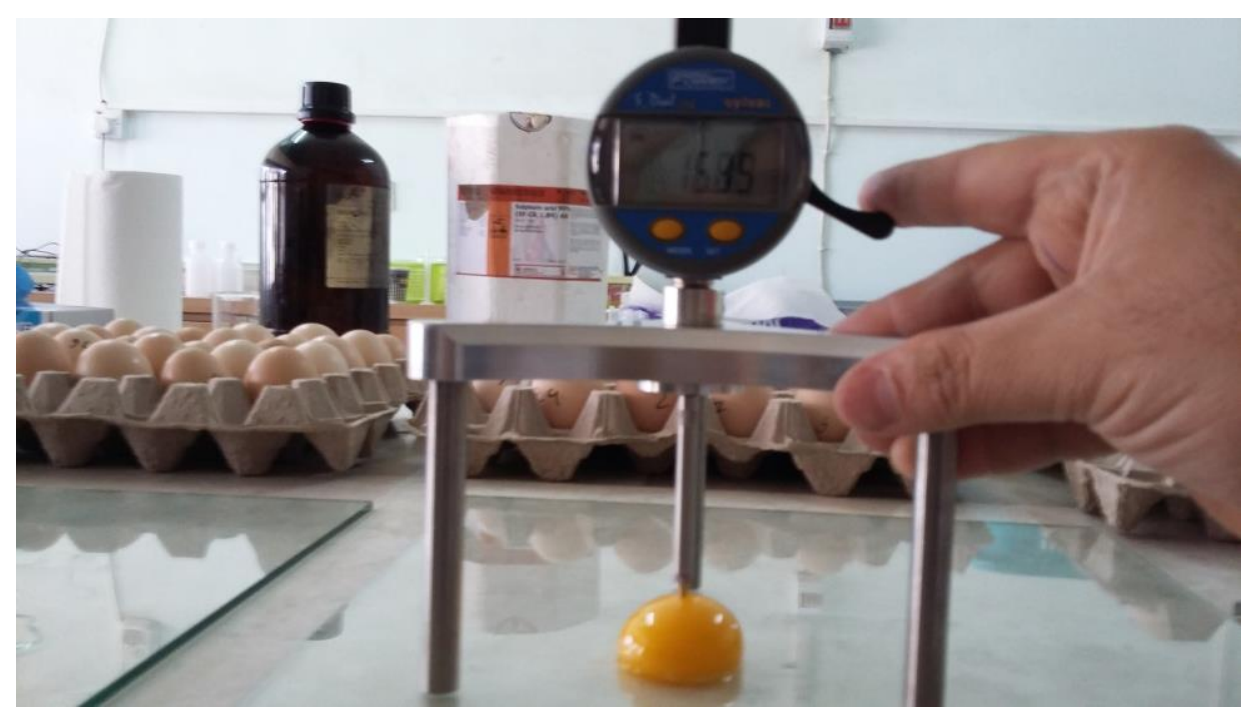

Figure 5. Spherometer used for measure yolk height

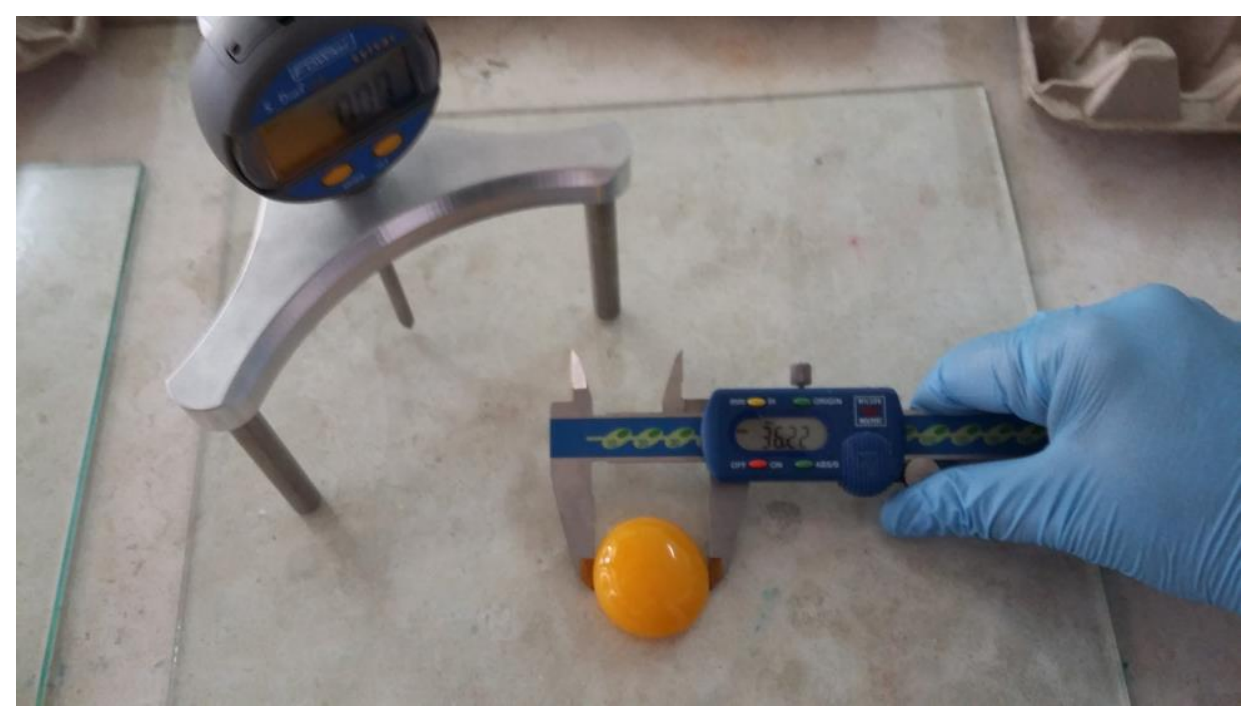

Figure 6. Digital Vernier used for measure yolk diameter

\section{Fertility and hatchability}

These traits were calculated by the following equations:

$$
\begin{gathered}
\text { Fertility } \%=\frac{\text { No. of fertile egg }}{\text { No. of total settable eggs }} \times 100 \\
\text { Total egg hatchability } \%=\frac{\text { No. of hatched chicks }}{\text { No. of total egg set }} \times 100
\end{gathered}
$$




$$
\text { Fertile egg hatchability } \%=\frac{\text { No. of hatched chicks }}{\text { No. of fertile eggs }} \times 100
$$

\section{Statistical analysis}

The present experiment was conducted using Completely Randomized Design (C.R.D) with three factors namely broiler breeder ages, storage periods and storage types to study the effect of these factors on the egg quality and hatchability traits. Statistical analysis was accomplished using (Xlstat-2017 Program for Windows version 19.6). Duncan's multiple range tests were used to determine the significance of differences among treatments means. Level of significance used in all results was $(\mathrm{P} \leq 0.05)$.

\section{Results}

\section{Egg weight (g) and albumin weight (g)}

The effects of interactions between broiler breeder ages, storage periods and storage types had significant $(\mathrm{p} \leq 0.05)$ effect on egg weight $(\mathrm{g})$ (Table 1$)$, the highest weight $(58.179 \mathrm{~g})$ was recorded by broiler breeder 50 weeks of age with 2 day of storage period and cooling condition of storage type and the lowest weight (46.931 g) was recorded by broiler breeder 35 weeks of age with 6 day of storage period and hot room condition of storage type.

Table 1. Effect of interactions between breeder ages, storage periods and storage types on egg weight $(g)$ and albumin weight $(g)$ (mean \pm SEM)

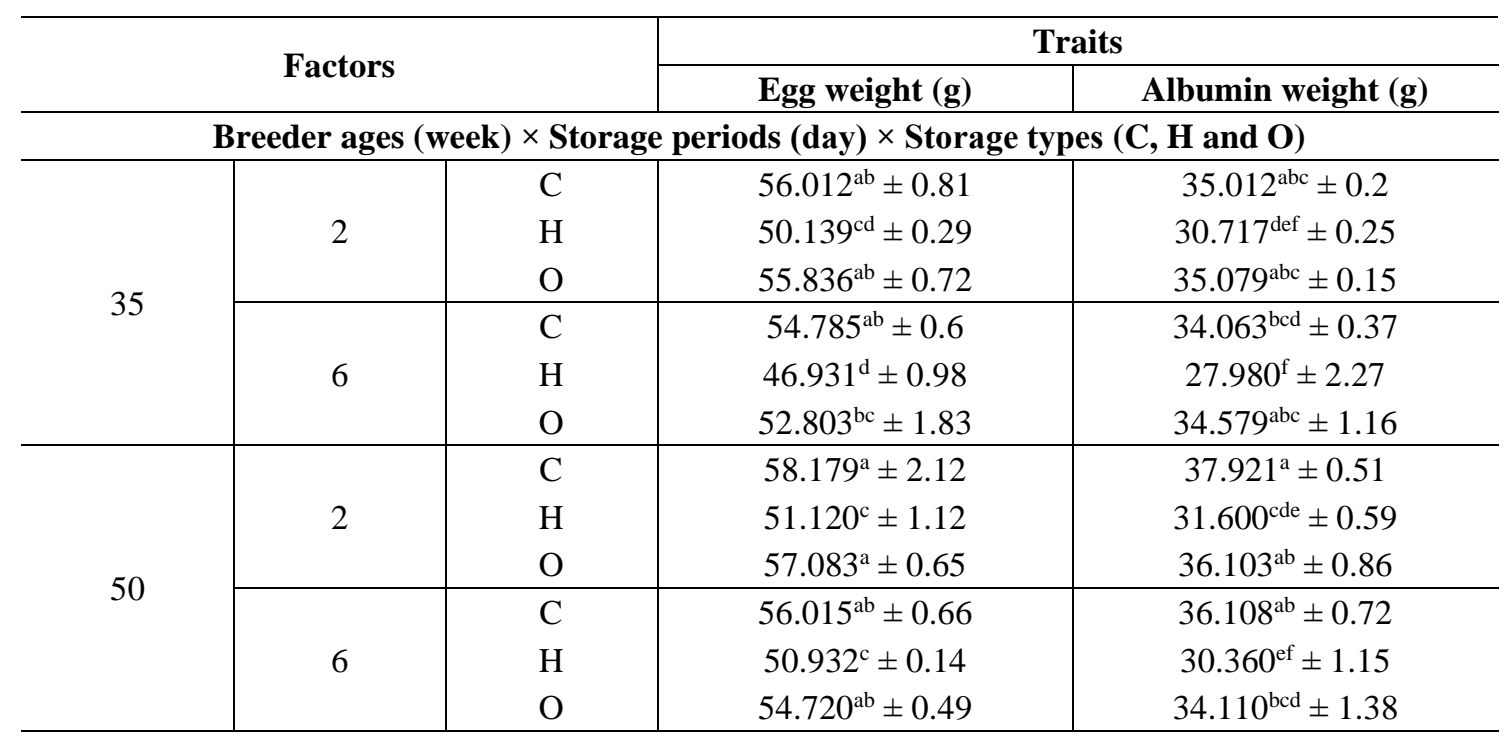

Mean values in the same column having different superscripts are significantly different at $\mathrm{P} \leq 0.05$. Mean values in the same column having the same superscripts are not significantly different at $\mathrm{P} \leq 0.05$. $\mathrm{C}=$ cooling, $\mathrm{H}=$ hot room $30 \mathrm{CO}$ and $\mathrm{O}=$ partially oil covered in hot room

The effects of interactions between broiler breeder ages, storage periods and storage types had significantly $(\mathrm{p} \leq 0.05)$ affected albumin weight $(\mathrm{g})$ (Table 1$)$, the highest weight of albumin (37.921 g) was recorded by broiler breeder 50 weeks of age with 
2 day of storage period and cooling condition of storage type and the lowest (27.980 g) was recorded by broiler breeder 35 weeks of age with 6 day of storage period and hot room condition of storage type.

\section{Yolk weight (g) and shell weight (g)}

The effects of interactions between broiler breeder ages, storage periods and storage types had significantly $(\mathrm{p} \leq 0.05)$ affected egg yolk weight $(\mathrm{g})$ (Table 2$)$, the highest value of yolk weight $(15.780 \mathrm{~g})$ was recorded by broiler breeder 50 weeks of age with 2 day of storage period and oil covered condition of storage type and the lowest $(12.360 \mathrm{~g})$ was recorded by broiler breeder 35 weeks of age with 6 day of storage period and oil covered condition of storage type. Also, there were no significant $(p \leq 0.05)$ effects of interactions between broiler breeder ages, storage periods and storage types on egg shell weight $(\mathrm{g})$ (Table 2).

Table 2. Effect of interactions between breeder ages, storage periods and storage types on yolk weight $(g)$ and shell weight $(g)$ (mean \pm SEM)

\begin{tabular}{|c|c|c|c|c|}
\hline & \multirow{2}{*}{ Factors } & & \multicolumn{2}{|c|}{ Traits } \\
\hline & & & Yolk weight (g) & Shell weight (g) \\
\hline \multicolumn{5}{|c|}{ Breeder ages $($ week $) \times$ Storage periods $($ day $) \times$ Storage types $(\mathrm{C}, \mathrm{H}$ and $\mathrm{O})$} \\
\hline \multirow{6}{*}{35} & \multirow{3}{*}{2} & $\mathrm{C}$ & $15.000^{\mathrm{a}} \pm 0.1$ & $6.000^{\mathrm{a}} \pm 0.12$ \\
\hline & & $\mathrm{H}$ & $13.668^{\mathrm{bc}} \pm 0.28$ & $5.754^{\mathrm{a}} \pm 0.19$ \\
\hline & & $\mathrm{O}$ & $14.131^{\mathrm{b}} \pm 0.06$ & $6.626^{\mathrm{a}} \pm 0.2$ \\
\hline & \multirow{3}{*}{6} & $\mathrm{C}$ & $14.200^{\mathrm{b}} \pm 1.63$ & $6.522^{\mathrm{a}} \pm 0.73$ \\
\hline & & $\mathrm{H}$ & $13.000^{\mathrm{c}} \pm 0.89$ & $5.951^{\mathrm{a}} \pm 0.32$ \\
\hline & & $\mathrm{O}$ & $12.360^{\mathrm{c}} \pm 1.02$ & $5.864^{\mathrm{a}} \pm 1.4$ \\
\hline \multirow{6}{*}{50} & \multirow{3}{*}{2} & $\mathrm{C}$ & $15.090^{\mathrm{a}} \pm 0.18$ & $5.168^{\mathrm{a}} \pm 0.26$ \\
\hline & & $\mathrm{H}$ & $14.800^{\mathrm{ab}} \pm 0.71$ & $4.720^{\mathrm{a}} \pm 0.03$ \\
\hline & & $\mathrm{O}$ & $15.780^{\mathrm{a}} \pm 0.06$ & $5.200^{\mathrm{a}} \pm 0.31$ \\
\hline & \multirow{3}{*}{6} & $\mathrm{C}$ & $15.110^{\mathrm{a}} \pm 0.32$ & $4.797^{\mathrm{a}} \pm 0.3$ \\
\hline & & $\mathrm{H}$ & $14.920^{\mathrm{ab}} \pm 0.24$ & $5.652^{\mathrm{a}} \pm 0.26$ \\
\hline & & $\mathrm{O}$ & $15.180^{\mathrm{a}} \pm 0.08$ & $5.430^{\mathrm{a}} \pm 0.76$ \\
\hline
\end{tabular}

Means values in the same column having different superscripts are significantly different at $\mathrm{P} \leq 0.05$. Means values in the same column having the same superscripts are not significantly different at $\mathrm{P} \leq 0.05 . \mathrm{C}=$ cooling, $\mathrm{H}=$ hot room $30 \mathrm{CO}$ and $\mathrm{O}=$ partially oil covered in hot room

\section{Albumin and yolk percentage}

The effects of interactions between broiler breeder ages, storage periods and storage types had a significant $(\mathrm{p} \leq 0.05)$ effect on albumin percentage (Table 3$)$, the highest value of albumin percentage $(65.487 \%)$ was recorded by broiler breeder 35 weeks of age with 6 day of storage period and oil covered condition of storage type and the lowest $(59.609 \%)$ was recorded by broiler breeder 50 weeks of age with 6 day of storage period and hot room condition of storage type.

The effects of interactions between broiler breeder ages, storage periods and storage types had a significant $(\mathrm{p} \leq 0.05)$ effect on yolk percentage (Table 3$)$, the highest value of yolk percentage (29.294\%) was recorded by broiler breeder 50 weeks of age with 
6 day of storage period and hot room condition of storage type and the lowest $(23.408 \%)$ was recorded by broiler breeder 35 weeks of age with 6 day of storage period and oil covered condition of storage type.

Table 3. Effect of interactions between breeder ages, storage periods and storage types on albumin and yolk percentage (mean \pm SEM)

\begin{tabular}{|c|c|c|c|c|}
\hline & \multirow{2}{*}{ Factors } & & \multicolumn{2}{|c|}{ Traits } \\
\hline & & & Albumin (\%) & Yolk $(\%)$ \\
\hline \multicolumn{5}{|c|}{ Breeder ages $($ week $) \times$ Storage periods $($ day $) \times$ Storage types $(\mathrm{C}, \mathrm{H}$ and $\mathrm{O})$} \\
\hline \multirow{6}{*}{35} & & $\mathrm{C}$ & $62.508^{\mathrm{abc}} \pm 0.1$ & $26.780^{\mathrm{abc}} \pm 0.23$ \\
\hline & 2 & $\mathrm{H}$ & $61.264^{\mathrm{bc}} \pm 0.49$ & $27.260^{\mathrm{ab}} \pm 0.2$ \\
\hline & & $\mathrm{O}$ & $62.825^{\mathrm{abc}} \pm 0.93$ & $25.308^{\mathrm{bc}} \pm 0.11$ \\
\hline & & $\mathrm{C}$ & $62.176^{\mathrm{abc}} \pm 0.36$ & $25.920^{\mathrm{abc}} \pm 0.16$ \\
\hline & 6 & $\mathrm{H}$ & $59.619^{c} \pm 0.42$ & $27.700^{\mathrm{ab}} \pm 0.29$ \\
\hline & & $\mathrm{O}$ & $65.487^{\mathrm{a}} \pm 0.2$ & $23.408^{\mathrm{c}} \pm 0.17$ \\
\hline \multirow{6}{*}{50} & & $\mathrm{C}$ & $65.180^{\mathrm{a}} \pm 0.51$ & $25.937^{\mathrm{abc}} \pm 0.4$ \\
\hline & 2 & $\mathrm{H}$ & $61.815^{\mathrm{abc}} \pm 0.25$ & $28.951^{\mathrm{ab}} \pm 0.18$ \\
\hline & & $\mathrm{O}$ & $63.247^{\mathrm{abc}} \pm 0.45$ & $27.644^{\mathrm{ab}} \pm 0.21$ \\
\hline & & $\mathrm{C}$ & $64.461^{\mathrm{ab}} \pm 0.21$ & $26.975^{\mathrm{abc}} \pm 0.11$ \\
\hline & 6 & $\mathrm{H}$ & $59.609^{c} \pm 0.33$ & $29.294^{\mathrm{a}} \pm 0.24$ \\
\hline & & $\mathrm{O}$ & $62.336^{\mathrm{abc}} \pm 0.36$ & $27.741^{\mathrm{ab}} \pm 0.22$ \\
\hline
\end{tabular}

Means values in the same column having different superscripts are significantly different at $\mathrm{P} \leq 0.05$. Means values in the same column having the same superscripts are not significantly different at $\mathrm{P} \leq 0.05 . \mathrm{C}=$ cooling, $\mathrm{H}=$ hot room $30 \mathrm{CO}$ and $\mathrm{O}=$ partially oil covered in hot room

\section{Shell percentage and yolk albumin ratio}

The effects of interactions between broiler breeder ages, storage periods and storage types had a significant $(\mathrm{p} \leq 0.05)$ effect on shell percentage (Table 4$)$, the highest value of shell percentage $(12.680 \%)$ was recorded by broiler breeder 35 weeks of age with 6 day of storage period and hot room condition of storage type and the lowest $(8.564 \%)$ was recorded by broiler breeder 50 weeks of age with 6 day of storage period and cooling condition of storage type. Also, there were no significant $(\mathrm{p} \leq 0.05)$ effects of interactions between broiler breeder ages, storage periods and storage types on yolk albumin ratio (Table 4).

\section{Albumin height (mm) and haugh unit}

The effects of interactions between broiler breeder ages, storage periods and storage types had a significant $(\mathrm{p} \leq 0.05)$ effect on Albumin height $(\mathrm{mm})($ Table 5), the highest value of albumin height $(7.500 \mathrm{~mm})$ was recorded by broiler breeder 50 weeks of age with 2 day of storage period and cooling condition of storage type and the lowest value $(3.400 \mathrm{~mm})$ was recorded by broiler breeder 35 weeks of age with 6 day of storage period and hot room condition of storage type.

The effects of interactions between broiler breeder ages, storage periods and storage types had a significant $(\mathrm{p} \leq 0.05)$ effect on Haugh unit (Table 5), the highest value of Haugh unit $(87.066 \mathrm{~mm})$ was recorded by broiler breeder 50 weeks of age with 2 day of 
storage period and cooling condition of storage type and the lowest $(59.202 \mathrm{~mm})$ was recorded by broiler breeder 35 weeks of age with 6 day of storage period and hot room condition of storage type.

Table 4. Effect of interactions between breeder ages, storage periods and storage types on shell percentage and yolk albumin ratio (mean \pm SEM)

\begin{tabular}{|c|c|c|c|c|}
\hline & \multirow{2}{*}{ Factors } & & \multicolumn{2}{|c|}{ Traits } \\
\hline & & & Shell (\%) & Yolk albumin ratio \\
\hline \multicolumn{5}{|c|}{ Breeder ages $($ week $) \times$ Storage periods $($ day $) \times$ Storage types $(\mathrm{C}, \mathrm{H}$ and $\mathrm{O})$} \\
\hline \multirow{6}{*}{35} & & $\mathrm{C}$ & $10.712^{\mathrm{ab}} \pm 0.12$ & $0.428^{\mathrm{a}} \pm 0$ \\
\hline & 2 & $\mathrm{H}$ & $11.476^{\mathrm{ab}} \pm 0.24$ & $0.445^{\mathrm{a}} \pm 0.01$ \\
\hline & & $\mathrm{O}$ & $11.867^{\mathrm{ab}} \pm 0.48$ & $0.403^{\mathrm{a}} \pm 0.01$ \\
\hline & & $\mathrm{C}$ & $11.905^{\mathrm{ab}} \pm 0.25$ & $0.417^{\mathrm{a}} \pm 0.005$ \\
\hline & 6 & $\mathrm{H}$ & $12.680^{\mathrm{a}} \pm 0.24$ & $0.465^{\mathrm{a}} \pm 0.008$ \\
\hline & & $\mathrm{O}$ & $11.105^{\mathrm{ab}} \pm 0.14$ & $0.357^{\mathrm{a}} \pm 0.005$ \\
\hline \multirow{6}{*}{50} & & $\mathrm{C}$ & $8.883^{\mathrm{ab}} \pm 0.27$ & $0.398^{\mathrm{a}} \pm 0.011$ \\
\hline & 2 & $\mathrm{H}$ & $9.233^{\mathrm{ab}} \pm 0.17$ & $0.468^{\mathrm{a}} \pm 0.005$ \\
\hline & & $\mathrm{O}$ & $9.110^{\mathrm{ab}} \pm 0.14$ & $0.437^{a} \pm 0.003$ \\
\hline & & $\mathrm{C}$ & $8.564^{\mathrm{b}} \pm 0.15$ & $0.418^{\mathrm{a}} \pm 0.003$ \\
\hline & 6 & $\mathrm{H}$ & $11.097^{\mathrm{ab}} \pm 0.15$ & $0.491^{\mathrm{a}} \pm 0.01$ \\
\hline & & $\mathrm{O}$ & $9.923^{\mathrm{ab}} \pm 0.22$ & $0.445^{\mathrm{a}} \pm 0$ \\
\hline
\end{tabular}

Means values in the same column having different superscripts are significantly different at $\mathrm{P} \leq 0.05$. Means values in the same column having the same superscripts are not significantly different at $\mathrm{P} \leq 0.05 . \mathrm{C}=$ cooling, $\mathrm{H}=$ hot room $30 \mathrm{CO}$ and $\mathrm{O}=$ partially oil covered in hot room

Table 5. Effect of interactions between breeder ages, storage periods and storage types on albumin height ( $\mathrm{mm}$ ) and haugh unit (mean \pm SEM)

\begin{tabular}{|c|c|c|c|c|}
\hline & \multirow{2}{*}{ Factors } & & \multicolumn{2}{|c|}{ Traits } \\
\hline & & & Albumin height (mm) & HU \\
\hline \multicolumn{5}{|c|}{ Breeder ages $($ week $) \times$ Storage periods $($ day $) \times$ Storage types $(\mathrm{C}, \mathrm{H}$ and $\mathrm{O})$} \\
\hline \multirow{6}{*}{35} & \multirow{3}{*}{2} & $\mathrm{C}$ & $6.990^{\mathrm{ab}} \pm 0.12$ & $84.64^{\mathrm{a}} \pm 1.2$ \\
\hline & & $\mathrm{H}$ & $4.100^{\mathrm{ab}} \pm 0.12$ & $64.677^{\mathrm{d}} \pm 1.02$ \\
\hline & & $\mathrm{O}$ & $6.300^{\mathrm{ab}} \pm 0.13$ & $80.207^{b} \pm 0.96$ \\
\hline & \multirow{3}{*}{6} & $\mathrm{C}$ & $5.030^{\mathrm{ab}} \pm 0.09$ & $70.949^{c} \pm 0.49$ \\
\hline & & $\mathrm{H}$ & $3.400^{b} \pm 0.02$ & $59.202^{\mathrm{e}} \pm 0.35$ \\
\hline & & $\mathrm{O}$ & $5.010^{\mathrm{ab}} \pm 0.03$ & $71.632^{c} \pm 0.49$ \\
\hline \multirow{6}{*}{50} & \multirow{3}{*}{2} & $\mathrm{C}$ & $7.500^{\mathrm{a}} \pm 0.03$ & $87.066^{\mathrm{a}} \pm 0.67$ \\
\hline & & $\mathrm{H}$ & $4.600^{\mathrm{ab}} \pm 0.04$ & $68.857^{c} \pm 0.22$ \\
\hline & & $\mathrm{O}$ & $7.300^{\mathrm{a}} \pm 0.07$ & $86.201^{\mathrm{a}} \pm 0.6$ \\
\hline & \multirow{3}{*}{6} & $\mathrm{C}$ & $7.100^{\mathrm{ab}} \pm 0.18$ & $85.314^{a} \pm 1.59$ \\
\hline & & $\mathrm{H}$ & $3.760^{\mathrm{ab}} \pm 0.18$ & $60.763^{\mathrm{e}} \pm 1.03$ \\
\hline & & $\mathrm{O}$ & $6.010^{\mathrm{ab}} \pm 0.11$ & $78.574^{b} \pm 0.84$ \\
\hline
\end{tabular}

Means values in the same column having different superscripts are significantly different at $\mathrm{P} \leq 0.05$. Means values in the same column having the same superscripts are not significantly different at $\mathrm{P} \leq 0.05 . \mathrm{C}=$ cooling, $\mathrm{H}=$ hot room $30 \mathrm{CO}$ and $\mathrm{O}=$ partially oil covered in hot room 


\section{Egg specific gravity and yolk height}

Also, The effects of interactions between broiler breeder ages, storage periods and storage types had significant $(\mathrm{p} \leq 0.05)$ effect on egg specific gravity (Table 6), the highest value (1.090) was recorded by both broiler breeder 35 and 50 weeks of age with 2 day of storage period and cooling condition of storage type and the lowest (1.070) was recorded by broiler breeder 35 weeks of age with 6 day of storage period and hot room condition of storage type, also, the value (1.070) obtained from breeders 50 weeks of age with 2 and 6 day of storage period and hot room condition of storage type.

The interactions between broiler breeder ages, storage periods and storage types had significant $(\mathrm{p} \leq 0.05)$ effect on yolk height $(\mathrm{mm})($ Table 6$)$, the highest value of yolk height $(19.290 \mathrm{~mm})$ was recorded by broiler breeder 50 weeks of age with 2 day of storage period and cooling condition of storage type and the lowest $(16.300 \mathrm{~mm})$ was recorded by broiler breeder 35 weeks of age with 6 day of storage period and hot room condition of storage type.

Table 6. Effect of interactions between breeder ages, storage periods and storage types on egg specific gravity and yolk height $(\mathrm{mm})($ Mean \pm SEM)

\begin{tabular}{|c|c|c|c|c|}
\hline & \multirow{2}{*}{ Factors } & & \multicolumn{2}{|c|}{ Traits } \\
\hline & & & Egg specific gravity & Yolk height (mm) \\
\hline \multicolumn{5}{|c|}{ Breeder ages $($ week $) \times$ Storage periods $($ day $) \times$ Storage types $(\mathrm{C}, \mathrm{H}$ and $\mathrm{O})$} \\
\hline \multirow{6}{*}{35} & \multirow{3}{*}{2} & $\mathrm{C}$ & $1.090^{\mathrm{a}} \pm 0.002$ & $18.640^{\mathrm{a}} \pm 0.12$ \\
\hline & & $\mathrm{H}$ & $1.075^{\mathrm{b}} \pm 0.001$ & $16.680^{b c} \pm 0.09$ \\
\hline & & $\mathrm{O}$ & $1.080^{\mathrm{ab}} \pm 0.002$ & $18.400^{\mathrm{a}} \pm 0.29$ \\
\hline & \multirow{3}{*}{6} & $\mathrm{C}$ & $1.080^{\mathrm{ab}} \pm 0.002$ & $17.480^{\mathrm{ab}} \pm 0.24$ \\
\hline & & $\mathrm{H}$ & $1.070^{\mathrm{b}} \pm 0$ & $16.300^{c} \pm 0.21$ \\
\hline & & $\mathrm{O}$ & $1.080^{\mathrm{ab}} \pm 0.001$ & $17.060^{\mathrm{ab}} \pm 0.18$ \\
\hline \multirow{6}{*}{50} & \multirow{3}{*}{2} & $\mathrm{C}$ & $1.090^{\mathrm{a}} \pm 0$ & $19.290^{\mathrm{a}} \pm 0.05$ \\
\hline & & $\mathrm{H}$ & $1.070^{\mathrm{b}} \pm 0.001$ & $18.120^{\mathrm{a}} \pm 0.15$ \\
\hline & & $\mathrm{O}$ & $1.080^{\mathrm{ab}} \pm 0.001$ & $19.260^{\mathrm{a}} \pm 0.05$ \\
\hline & \multirow{3}{*}{6} & $\mathrm{C}$ & $1.080^{\mathrm{ab}} \pm 0.001$ & $18.590^{\mathrm{a}} \pm 0.11$ \\
\hline & & $\mathrm{H}$ & $1.070^{\mathrm{b}} \pm 0.001$ & $17.510^{\mathrm{ab}} \pm 0.13$ \\
\hline & & $\mathrm{O}$ & $1.075^{\mathrm{b}} \pm 0$ & $18.390^{\mathrm{a}} \pm 0.23$ \\
\hline
\end{tabular}

Means values in the same column having different superscripts are significantly different at $\mathrm{P} \leq 0.05$. Means values in the same column having the same superscripts are not significantly different at $\mathrm{P} \leq 0.05$. $\mathrm{C}=$ cooling, $\mathrm{H}=$ hot room $30 \mathrm{CO}$ and $\mathrm{O}=$ partially oil covered in hot room

\section{Yolk diameter (mm) and yolk index}

The interactions between broiler breeder ages, storage periods and storage types had a significant $(\mathrm{p} \leq 0.05)$ effect on yolk diameter $(\mathrm{mm})$ (Table 7$)$, the highest value of yolk diameter $(40.110 \mathrm{~mm}$ ) was recorded by broiler breeder 50 weeks of age with 6 day of storage period and hot room condition of storage type and the lowest value $(35.280 \mathrm{~mm})$ was recorded by broiler breeder 35 weeks of age with 2 day of storage period and cooling condition of storage type. 
The interactions between broiler breeder ages, storage periods and storage types had significant $(\mathrm{p} \leq 0.05)$ effects on yolk index (Table 7$)$, the highest value of yolk index (0.544) was recorded by broiler breeder 50 weeks of age with 2 day of storage period and cooling condition of storage type and the lowest value (0.408) was recorded by broiler breeder 35 weeks of age with 6 day of storage period and hot room condition of storage type.

Table 7. Effect of interactions between breeder ages, storage periods and storage types on yolk diameter $(\mathrm{mm})$ and yolk index (mean \pm SEM)

\begin{tabular}{|c|c|c|c|c|}
\hline & \multirow{2}{*}{ Factors } & & \multicolumn{2}{|c|}{ Traits } \\
\hline & & & Yolk diameter $(\mathrm{mm})$ & Yolk index \\
\hline \multicolumn{5}{|c|}{ Breeder ages $($ week $) \times$ Storage periods $($ day $) \times$ Storage types $(C, H$ and $O)$} \\
\hline \multirow{6}{*}{35} & & $\mathrm{C}$ & $35.280^{\mathrm{d}} \pm 0.16$ & $0.528^{\mathrm{a}} \pm 0.47$ \\
\hline & 2 & $\mathrm{H}$ & $38.570^{\mathrm{abcd}} \pm 0.41$ & $0.432^{\mathrm{ef}} \pm 0.51$ \\
\hline & & $\mathrm{O}$ & $36.140^{\mathrm{cd}} \pm 0.24$ & $0.509^{\mathrm{ab}} \pm 0.44$ \\
\hline & & $\mathrm{C}$ & $35.910^{\mathrm{cd}} \pm 0.28$ & $0.486^{\mathrm{bc}} \pm 0.46$ \\
\hline & 6 & $\mathrm{H}$ & $39.890^{\mathrm{ab}} \pm 0.2$ & $0.408^{\mathrm{f}} \pm 0.47$ \\
\hline & & $\mathrm{O}$ & $36.440^{\mathrm{bcd}} \pm 0.16$ & $0.468^{\mathrm{cd}} \pm 0.45$ \\
\hline \multirow{6}{*}{50} & & $\mathrm{C}$ & $35.410^{\mathrm{d}} \pm 0.22$ & $0.544^{\mathrm{a}} \pm 0.44$ \\
\hline & 2 & $\mathrm{H}$ & $39.450^{\mathrm{abc}} \pm 1.28$ & $0.459^{\text {cde }} \pm 0.57$ \\
\hline & & $\mathrm{O}$ & $35.830^{\mathrm{cd}} \pm 0.16$ & $0.537^{\mathrm{a}} \pm 0.45$ \\
\hline & & $\mathrm{C}$ & $35.780^{\text {cd }} \pm 0.08$ & $0.519^{\mathrm{ab}} \pm 0.44$ \\
\hline & 6 & $\mathrm{H}$ & $40.110^{\mathrm{a}} \pm 0.31$ & $0.436^{\mathrm{def}} \pm 0.47$ \\
\hline & & $\mathrm{O}$ & $36.010^{\text {cd }} \pm 0.35$ & $0.510^{\mathrm{ab}} \pm 0.45$ \\
\hline
\end{tabular}

Means values in the same column having different superscripts are significantly different at $\mathrm{P} \leq 0.05$. Means values in the same column having the same superscripts are not significantly different at $\mathrm{P} \leq 0.05 . \mathrm{C}=$ cooling, $\mathrm{H}=$ hot room $30 \mathrm{CO}$ and $\mathrm{O}=$ partially oil covered in hot room

\section{Hatchability and fertility percentage}

The interactions between broiler breeder ages, storage periods and storage types had a significant $(\mathrm{p} \leq 0.05)$ effect on value of hatchability (Table 8$)$, the highest value $(91.00 \%)$ of hatchability was recorded by broiler breeder 50 weeks of age with 2 day of storage period and cooling condition of storage type and the lowest value $(32.33 \%)$ was recorded by broiler breeder 50 weeks of age with 6 day of storage period and hot room condition of storage type. Also, there were no significant $(\mathrm{p} \leq 0.05)$ effects of interactions between broiler breeder ages, storage periods and storage types on fertility (Table 8).

\section{Fertile egg hatchability}

The interactions between broiler breeder ages, storage periods and storage types had significant $(\mathrm{p} \leq 0.05)$ effect on values of fertile egg hatchability percentage (Table 9), the highest value $(96.26 \%)$ of fertile egg hatchability was recorded by broiler breeder 35 weeks of age with 2 day of storage period and cooling condition of storage type and the lowest value $(35.14 \%)$ was recorded by broiler breeder 50 weeks of age with 6 day of storage period and hot room condition of storage type. 
Table 8. Effect of interactions between breeder ages, storage periods and storage types on hatchability and fertility eggs percentage (mean \pm SEM)

\begin{tabular}{|c|c|c|c|c|}
\hline & \multirow{2}{*}{ Factors } & & \multicolumn{2}{|c|}{ Traits } \\
\hline & & & Hatchability (\%) & Fertility (\%) \\
\hline \multicolumn{5}{|c|}{ Breeder ages $($ week $) \times$ Storage periods $($ day $) \times$ Storage types $(\mathrm{C}, \mathrm{H}$ and $\mathrm{O})$} \\
\hline \multirow{6}{*}{35} & \multirow{3}{*}{2} & $\mathrm{C}$ & $90.00^{\mathrm{a}} \pm 4.83$ & $93.50^{\mathrm{a}} \pm 4.67$ \\
\hline & & $\mathrm{H}$ & $63.33^{\mathrm{d}} \pm 6.71$ & $94.33^{\mathrm{a}} \pm 8.56$ \\
\hline & & $\mathrm{O}$ & $77.00^{\mathrm{c}} \pm 11.76$ & \pm 7.99 \\
\hline & \multirow{3}{*}{6} & $\mathrm{C}$ & $85.50^{\mathrm{b}} \pm 4.27$ & $92.50^{\mathrm{a}} \pm 10.03$ \\
\hline & & $\mathrm{H}$ & $40.00^{\mathrm{f}} \pm 2.36$ & $91.67^{\mathrm{a}} \pm 7.66$ \\
\hline & & $\mathrm{O}$ & $51.00^{\mathrm{e}} \pm 3.79$ & $92.00^{\mathrm{a}} \pm 11.02$ \\
\hline \multirow{6}{*}{50} & \multirow{3}{*}{2} & $\mathrm{C}$ & $91.00^{\mathrm{a}} \pm 4.44$ & $95.00^{\mathrm{a}} \pm 8.01$ \\
\hline & & $\mathrm{H}$ & $64.00^{\mathrm{d}} \pm 10$ & $93.00^{\mathrm{a}} \pm 10.41$ \\
\hline & & $\mathrm{O}$ & $77.33^{\mathrm{c}} \pm 5.88$ & $92.33^{\mathrm{a}} \pm 8.89$ \\
\hline & \multirow{3}{*}{6} & $\mathrm{C}$ & $83.00^{b} \pm 7.41$ & $91.50^{\mathrm{a}} \pm 5.56$ \\
\hline & & $\mathrm{H}$ & $32.33^{\mathrm{g}} \pm 8.82$ & \pm 10 \\
\hline & & $\mathrm{O}$ & $50.00^{\mathrm{e}} \pm 3.41$ & $94.00^{\mathrm{a}} \pm 4.24$ \\
\hline
\end{tabular}

Means values in the same column having different superscripts are significantly different at $\mathrm{P} \leq 0.05$. Means values in the same column having the same superscripts are not significantly different at $\mathrm{P} \leq 0.05 . \mathrm{C}=$ cooling, $\mathrm{H}=$ hot room $30 \mathrm{CO}$ and $\mathrm{O}=$ partially oil covered in hot room

Table 9. Effect of interactions between breeder ages, storage periods and storage types on fertile egg hatchability percentage (mean \pm SEM)

\begin{tabular}{|c|c|c|c|}
\hline & \multirow{2}{*}{ Factors } & & Traits \\
\hline & & & Fertile egg hatchability $(\%)$ \\
\hline \multicolumn{4}{|c|}{ Breeder ages $($ week $) \times$ Storage periods $($ day $) \times$ Storage types $(C, H$ and $O)$} \\
\hline \multirow{6}{*}{35} & \multirow{3}{*}{2} & $\mathrm{C}$ & $96.26^{\mathrm{a}} \pm 4.52$ \\
\hline & & $\mathrm{H}$ & $67.14^{\mathrm{d}} \pm 14.43$ \\
\hline & & $\mathrm{O}$ & $82.50^{\mathrm{c}} \pm 14.43$ \\
\hline & \multirow{3}{*}{6} & $\mathrm{C}$ & $92.43^{b} \pm 19.25$ \\
\hline & & $\mathrm{H}$ & $43.64^{\mathrm{f}} \pm 10.99$ \\
\hline & & $\mathrm{O}$ & $55.43^{\mathrm{e}} \pm 14.53$ \\
\hline \multirow{6}{*}{50} & \multirow{3}{*}{2} & $\mathrm{C}$ & $95.79^{\mathrm{a}} \pm 10.32$ \\
\hline & & $\mathrm{H}$ & $68.82^{\mathrm{d}} \pm 11.25$ \\
\hline & & $\mathrm{O}$ & $83.75^{c} \pm 9.87$ \\
\hline & \multirow{3}{*}{6} & $\mathrm{C}$ & $90.71^{b} \pm 7.66$ \\
\hline & & $\mathrm{H}$ & $35.14^{\mathrm{g}} \pm 16.67$ \\
\hline & & $\mathrm{O}$ & $53.19^{\mathrm{e}} \pm 3.82$ \\
\hline
\end{tabular}

Means values in the same column having different superscripts are significantly different at $\mathrm{P} \leq 0.05$. Means values in the same column having the same superscripts are not significantly different at $\mathrm{P} \leq 0.05$. $\mathrm{C}=$ cooling, $\mathrm{H}=$ hot room $30 \mathrm{CO}$ and $\mathrm{O}=$ partially oil covered in hot room 


\section{Discussion}

The increase of egg weight with advancing age of broiler breeders (older breeders) may be due to increase the parts of egg components (especially yolk and albumin weight) giving more growth and activation of the reproductive system of broiler breeders compared to younger breeders. This can be explained by the associated increase in egg weight with age. Similar results were reported by several investigators with respect to egg weight increase with advancing age of broiler breeders (Javid et al., 2016; Akyurek and Okur, 2009; Yildirim, 2005; Vieira et al., 2005).

Also, the results of the present study indicated that egg weight of fresh egg decreased and egg weight loss increased with prolonged eggs storage period and storage condition. When the storage period is extended the egg weight declines due to loss of moisture from the egg, and the value of egg weight in oil covered was similar to eggs stored in cooling condition, because of the oil covered condition preventing the loss of more moisture from the eggs compared with un covered eggs in the hot room. These results with respect to the effect of storage period on egg weight loss agreed with those of Reijrink et al. (2010) and Gonzalez (2010).

Gualhanone et al. (2011) also, showed that heavier eggs resulted in heavier chicks, as expected, corroborating several authors that reported a positive correlation between egg weight and chick weight, older breeders with heavier eggs produced heavier chicks, irrespective of incubation temperature, chick weight is an important factor in broiler growth, since it was reported that there is a positive and strong correlation between chick weight at hatch and broiler market weight (42 to 45 days of age). Similar results were reported by several investigators with respect to egg weight increase with advancing age of breeders (Yildirim, 2005; Vieira et al., 2005; Zakaria et al., 2009). This severe effect of older breeders may be considered as a method of improving the percentage of high quality chicks obtained from older breeders.

The increase in the albumin egg weight in older breeders may be due to more growth and activation of the reproductive system of females compared to younger breeders (Javid et al., 2016). And albumin weight was decreased with a longer storage period of egg and storage condition, this is caused by water loss or migration from the albumin. These results were in agreement with the suggestions of Yeasmin et al. (2014) and Jin et al. (2011) whom reported that the albumin weight was greatly influenced by the storage temperature condition and storage period of the eggs.

Generally, the present study showed that the interaction between the main factors showed clearly the decreased the egg weight and albumin weight for old broiler breeders (50 weeks), this was may be due to the storage periods and storage condition that caused the loss of moisture from the egg. The present results are very similar to those reported by Reijrink et al. (2010), Gonzalez-Redondo (2010) and Jin et al. (2011).

Yolk weight increasing by progressing the age may be due to more activation of reproductive system of females and liver activity compared to younger breeders; these results were similar to the finding by Javid et al. (2016) that recorded the increase in egg components by old breeders compared with young breeders. And yolk weight increased with a longer storage period of egg and storage condition this was caused by some of water migration from the albumin to the yolk, these finding of the present study were in agreement with chose by several authors (Khan et al., 2014, 2013; Demirel and Kirikci, 2009) who reported positive correlation between increased yolk weight with increased storage periods and condition. The interaction between the main factors showed clearly the increase of yolk weight for old broiler breeders ( 50 weeks) was caused by activity of 
reproductive system of females and liver, and for storage periods and conditions, this was may be due to the and migration of moisture from the albumin to the yolk. The results were very similar to the results reported by Javid et al. (2016), Khan et al. (2014, 2013) and Demirel and Kirikci (2009).

According to the present results there were no effects of main factors and their interactions on shell weight, however, numerically shell weight increased with advancing of age in broiler breeders and the other factors (storage periods and storage conditions) had no effect on shell weight. These findings were in line with Yeasmin et al. (2014), Akyurek and Okur (2009) and Silversides and Scott (2001), who reported no effect of storage period and storage temperature on egg shell weight.

Albumin and yolk percentage of eggs were affected significantly by storage conditions and the interaction between broiler breeder ages, storage periods and storage conditions. When decreased albumin ratio already increased yolk ratio, this was because albumin loses more water than yolk, which caused a proportional increase in yolk ratio. The results were similar to the finding of Demirel and Kirikci (2009) and Kırıkçı et al. (2005) whom found the effect of storage period on albumin and yolk percentage.

The cause of affecting of interaction between broiler breeder ages, storage periods and storage type conditions on increasing of shell percentage may be due to decrease of other eggs component ratio during storage period. Shell ratio determined in the present study was similar to the finding of Demirel and Kirikci (2009).

According to the results there were no effects of main factors and their interactions on yolk albumin ratio. However, numerically there was a little difference between the interactions of main factors; this is may be due to the variety and the proportion of the yolk and albumin of eggs during the storage periods and storage conditions. These results were in agreement with those suggested by Suk and Park (2001).

In the present study, there was not effect of broiler breeder ages on albumin height, but there was a significantly effect of interactions between broiler breeder ages with storage temperature condition on albumin height. These results were consistent with the findings of Yeasmin et al. (2014) and Silversides and Scott (2001), who reported the reduction of albumin height was due to the decrease in thick albumen height, because of breakdown of the ovomucin-lysozyme complex during storage periods.

In the present study the storage of eggs clearly reducing of (HU) between young and older breeders. Also, these disparate effects caused by the influence of interaction of age with storage (Tona et al., 2004), these results may be due to increase of egg weight and albumin height of eggs from old broiler breeders compared to young broiler breeders. This result of reduced HU was due to age of broiler breeders or storage periods which were consistent with the reports of Akyurek and Okur (2009), Tona et al. (2004) and Silversides and Scott (2001).

The results showed that Haugh unit values decreased with increased egg storage periods and conditions in the present study, water loss from the egg, or migration of water from the albumen to the yolk or evaporation from the eggs components is the most likely reason of it. These results were consistent with the findings of Monira et al. (2003), who reported that values decreased with storage period. The present results relating to the effect of storage period on Haugh unit were similar with the findings of Grashorn et al. (2016), Alsobayel and Albadry (2011), Nowaczewski et al. (2010), Demirel and Kirikçi (2009) and Tilki and Saatçi (2004), who reported that the Haugh unit significantly decreased with increasing days of storage, due to loss of water from the eggs. 
There was no significant effect of broiler breeder ages on egg specific gravity, these results were in agreement with Gualhanone et al. (2011) and Akyurek and Okur (2009), who reported that no effect of breeder age on (ESG). On the other hand, specific gravity of eggs declined gradually with the advancing storage period as a resulted in maximum decreases at hot room of storage condition in both covered and non-covered with oil, but the specific gravity of eggs kept at room temperature declined more rapidly than that of cooling temperature condition, this might be due to the size of the air cell with increase of storage period and temperature the size of the air cell increased. These results were in agreement with Yeasmin et al. (2014), Alsobayel and Albadry (2011) and Akyurek and Okur (2009), who observed the size of the air cell increased with different storage temperatures.

In the present study the yolk height values were increased by advancing the age of broiler breeders, this was may be due to the size of yolk in heavy egg (this was clearly observed in continued Table 1 that the highest egg weight $(58.179 \mathrm{~g})$ was recorded by broiler breeder 50 weeks of age with 2 day of storage period and cooling condition of storage type) compared to light egg, but yolk height decreased with increase of storage periods and storage temperature, this was may be due to the decrease of the strength of vitelline membrane that caused loss a little of water from the yolk and finally it caused the change in yolk index value. These results were confirmed with Abdel-Azim and Farahat (2009) and Günlü et al. (2007), who found the change of yolk index value under the effect of changing yolk height value.

The increase in yolk diameter observed in the present study could be due to decrease of the strength of vitelline membrane. When eggs are stored under room temperature for long periods, the strength of vitelline membrane breaks which makes the yolk to spread into the albumin. These results were in agreement with Kirunda and McKee (2000), who reported that vitelline membrane strength decreases during storage and makes the yolk more susceptible to breaking, as a result, water slowly enters into the yolk from the albumen, so this creates a mottled appearance in yolk, and the yolk becomes flattened. The yolk diameter values were higher in room temperature, because at a very high temperature, the amount of water migration from the albumen to the yolk is high, which helped to increase yolk diameter (Yeasmin et al., 2014).

The results of Table 7 also showed that the yolk index (YI) values were significantly decrease with increased storage periods which was most likely due to water loss from the egg. On the other hands, the yolk index values equation depended on the yolk height and yolk diameter, when the yolk diameter increased with increase storage periods and conditions which resulted in an increase the YI values. These results were similar to those found by Abdel-Azim and Farahat (2009), Günlü et al. (2007), Gupta et al. (2007) and Kuzniacka et al. (2005).

The results in the present study showed that hatchability percentage was significantly affected by ages of broiler breeders, storage periods and storage type conditions. These results may be return to the effect of these factors on the egg quality; changes in the quality of eggs can affect the embryonic development during the incubation period and finally the hatchability results. On the basis of the results obtained, it can be concluded that present results in this study were confirmed by Sebastian et al. (2016), who found the lower levels of hatchability parameters were recorded in Ross 308 broiler breeders over 40th weeks of age. Hatchability was significantly lower in the eggs incubated at high ambient temperature (Gualhanone et al., 2011). Some negative changes in egg quality of all poultry species were reported due to prolonged storage period. For 
example, water loss from eggs was related to hatchability (Kozuszek et al., 2009). Also, variations in hatchability may be explained various factors, such as: storage duration, care of hatching eggs, age of breeder, age of broody birds, quality of eggs, seasons, nutrition (Miazi et al., 2012).

The hatchability values recorded by Khan et al. (2013), Mustafa and Al-Sardary (2009), Reijrink et al. (2009), Demirel and Kırıkçı (2009) and Fasenko et al. (2001b) were very close to the results of the present study. Some embryos of eggs stored for a long period could not begin developing instantly after normal incubation temperatures were provided. Khan et al. (2013) found the significant differences in the hatchability of the total of the incubated eggs according to the duration of the storage period before the incubation.

Mustafa and Al-Sardary (2009) finding that the highest hatchability percentage was obtained in the young breeders (33 weeks) compared with old breeders (53 weeks).

Also, Reijrink et al. (2009) noted the detrimental or beneficial effect of pre-storage incubation when storage period was prolonged. Hatchability characteristics were affected by storage period, decreasing with increased storage period, similar results were found by Demirel and Kırıkçı (2009).

According to Fasenko et al. (2001b), the effect of pre-storage incubation on hatchability when storage period is prolonged depends on the developmental stage of the embryo after pre-storage incubation.

According to the present results there were no significant effects of storage periods and storage conditions on the fertility percentage, these results may be due the occurrence of the fertilization of the eggs in the fundamental part of female reproductive system inside the body therefore these factors did not affect on the fertility percentage.

On the other hands, it was shown that the eggs' fertility depends on various factors, such as: age, breed, season, lighting, level of nutrition, time of mating and number of mail with females (Miazi et al., 2012).

Fertility percentage found in the present study was similar to fertility percentage reported in previous studies of Khan et al. (2014) and Demirel and Kırıkç1 (2009), who reported that there was no positive or negative effect of storage period on the fertility value.

According to the results of the present study there were significant effects of main factors and their interactions on hatchability of fertile eggs. Hatchability of fertile eggs also may be influenced by same factors that affected total hatchability such as storage duration, care of hatching eggs, age of broody birds, quality of eggs, seasons and nutrition (Miazi et al., 2012). Also, Mustafa and Al-Sardary (2009) found that the highest hatchability of fertile eggs percentage was obtained in the young breeders (33 weeks) compared with old breeders (53 weeks). In embryos less or further advanced damage caused by prolonged storage period might be irreversible and sometimes might cause embryonic mortality. Similarly, Tona et al. (2001) reported the process of embryo development in Cobb hens at different ages (27-60 weeks) also reported a rapid increase in the total embryonic mortality during incubation of eggs laid by older hens (4664 weeks of age). Significant differences were found in the hatchability of the fertile eggs according to the duration of the storage period before the incubation conducted by Khan et al. (2013).

Reijrink et al. (2009) found that hatchability of fertile eggs in broiler breeder stored for 3,5 and $8 \mathrm{~d}$ were higher than hatchability of fertile eggs stored for $12 \mathrm{~d}$ at $16{ }^{\circ} \mathrm{C}$ to $18{ }^{\circ} \mathrm{C}$. 
Some embryos could not begin developing immediately after normal incubation temperatures if stored for a long period reported by Tona et al. (2001).

In conclusion, some of the quality traits of the eggs were significantly affected by broiler breeder ages, storage periods and storage types such as: egg weight, albumin weight, yolk weight, haugh unit, yolk height, yolk index, hatchability and fertile egg hatchability percentage.

\section{Conclusions}

Some of the quality traits of the eggs were significantly affected by broiler breeder ages, storage periods and storage types such as: egg weight, albumin weight, yolk weight, haugh unit, yolk height, yolk index, hatchability and fertile egg hatchability percentage. According to the results of the present study, the following points can be recommended: If the purpose of eggs production was for hatching, we recommend purchasing eggs laid by younger breeders than older breeders that is useful for owners of the hatcheries, but if the purpose of eggs production was for table eggs (consumption) we recommend to purchasing the eggs laid by older layers than younger layers that is useful for the commercial sellers and for consumers. Also, the best storage condition for storage (keeping) the eggs was under the cooling condition, but if this condition is not prepared because of disorder or disable of hatcheries machine, disconnect of electric source or prepare the large number of the eggs we recommended storage the eggs under oil covered condition (partially covered by oil) for short period (1-2 days) to prevent the water loss from the eggs.

\section{REFERENCES}

[1] Abdel-Azim, A. M., Farahat, G. S. (2009): Breed differences and phenotypic correlations of antioxidant enzymes activities, some physiological parameters and productive traits of chicken. Phenotypic correlations. - Egypt. P. Sci. J. 29: 645-666.

[2] Akyurek, H., Okur, A. A. (2009): Effect of storage time, temperature and hen age on egg quality in free-range layer hens. - J. of A. and V. A. 8: 1953-1958.

[3] Alsobayel, A. A., Albadry, M. A. (2011): Effect of storage period and strain of layer on internal and external quality characteristics of eggs marketed in Riyadh area. - J. of the Saudi S. of A. Sci. 10: 41-45.

[4] Christensen, V. L., Grimes, J. L., Wineland, M. J. (2001): Effects of breeder hen age, strain, and length of the incubation period on survival of embryos and hatchlings. - J. Appl. Poult. Res. 10: 5-15.

[5] Demirel, Ş., Kırıkçı, K. (2009): Effect of different egg storage times on some egg quality characteristics and hatchability of pheasants (Phasianus colchicus). - Poultry Sci. 88: 440-444.

[6] Elibol, O., Peak, S. D., Brake, J. (2002): Effect of flock age, length of egg storage, and frequency of turning during storage on hatchability of broiler hatching eggs. - Poult. Sci. 81: 945-950.

[7] Fasenko, G. M. (2007): Egg storage and the embryo. - Poult. Sci. 86: 1020-1024.

[8] Fasenko, G. M., Christensen, V. L., Wineland, M. J., Petitte, J. N. (2001a). Examining the effects of pre-storage incubation of turkey breeder eggs on embryonic development and hatchability of eggs stored for four to fourteen days. - Poult. Sci. 80: 132-138.

[9] Fasenko, G. M., Robinson, F. E., Whelan, A. I., Kremeniuk, K. M., Walker, J. A. (2001b): Prestorage incubation of long-term stored broiler breeder eggs effects on hatchability. - Poult. Sci. 80: 1406-1411. 
[10] Feddern, V., Celant De Prá, M., Mores, R., da Silveira Nicoloso, R., Coldebella, A., Giovanni de, A. P. (2017): Egg quality assessment at different storage conditions, seasons and laying hen strains. - Ciência e Agrotecnologia 41(3): 322-333.

[11] Gonzalez, R. (2010): Effect of long-term storage on the hatchability of red-legged partridge (Alectoris rufa) eggs. - Poultry Sci. 89: 379-383.

[12] Gualhanone, A., Furlan, R. L., Fernandez-Alarcon, M. F., Macari, M. (2011): Effect of Breeder Age on Eggshell Thickness, Surface Temperature, Hatchability and Chick Weigh. - Brazilian J. of P. Sci. 14(1): 09-14.

[13] Guibert, F., Richard-Yris, A. M., Lumineau, S., Kotrschal, K., Möstl, E., Houdelier, C. (2012): Yolk testosterone levels and offspring phenotype correlate with parental agein aprecocial bird. - Physiol. Behav. 105: 242-250.

[14] Günlü, A., Kırıkçı, K., Çetin, O., Garip, M. (2007): Effect of hen age on some egg quality characteristics of Pheasants (P. colchicus). Current Problems of Breeding, Health. Growth and Production of Poultry Congress (February 14-17). Ceske Budejovice, Czech Republic, pp. 211-215.

[15] Gupta, C. S., Kumar, A., Arya, R., Patel, M., Ghosh, A. K., Palod, J. (2007): Evaluation of egg quality of crossbred chickens reared under backyard farming in Tarai areas of Uttaranchal. - Indian J. Anim. Res. 41: 216-219.

[16] Hamidu, J. A., Rieger, A. M., Fasenko, G. M., Barreda, D. R. (2010): Dissociation of chicken blastoderm for examination of apoptosis and necrosis by flow cytometry. - Poult. Sci. 89: 901-909.

[17] Hulet, R., Gladys, G., Hill, D., Meijerhof, R., El-Shiekh, T. (2007): Influence of eggshell embryonic incubation temperature and broiler breeder flock age on posthatch growth performance and carcass characteristics. - Poul. Sci. 86: 408-412.

[18] Javid, I., Sohail, H. K., Nasir, M., Tanveer, A., Riaz, A. P. (2016): Effects of egg size (weight) and age on hatching performance and chick quality of broiler breeder. - Journal of Applied Animal Research 44(1): 54-64. DOI: 10.1080/09712119.2014.987294.

[19] Jin, Y. H., Lee K. T., Lee W. I., Han Y. K. (2011): Effects of Storage Temperature and Time on the Quality of Eggs from Laying Hens at Peak Production. - Asian-Aust. J. Anim. Sci. 24(2): 279-284.

[20] Khan, M. J. A., Khan, S. H., Bukhsh, A., Abbass, M. I., Javed, M. (2013): Effect of Different Storage Period on Egg Weight, Internal Egg Quality and Hatchability Characteristics of Fayumi Eggs. - Italian J. of A. S. 12: 2: e51. DOI: 10.4081/ijas.2013.e51.

[21] Khan, M. J. A., Khan, S. H., Bukhsh, A., Abbass, M. I. (2014): The effect of storage time on egg quality and hatchability characteristics of Rhode Island Red (RIR) hens. Veterinarski Arhiv 84(3): 291-303.

[22] Kırıkçı, K., Günlü, A., Garip, M. (2005): Some quality characteristics of Pheasant ( $P$. colchicus) eggs which different shell colors. - Türk. J. Vet. Anim. Sci. 29: 315-318.

[23] Kirunda, D. F. K., McKee, S. R. (2000): Relating quality characteristics of aged eggs and fresh eggs to vitelline membrane strength as determined by a texture analyzer. - Poultry Science 79(8): 1189-1193.

[24] Kozuszek, R., Kontecka, H., Nowaczewski, S., Rosiñski, A. (2009): Storage time and eggshell colour of pheasant eggs vs. the number of blastodermal cells and hatchability results. - Folia Biologica (Kraków) 57: 121-130.

[25] Kuzniacka, J., Bernacki, Z., Adamski, M. (2005): Effect of the date of egg-laying on the biological value of eggs and reproductive traits in pheasants (Phasianus colchicuc L.). Folia Biol. (Krakow) 53: 73-78.

[26] Miazi, O. F., Miah, G., Miazi, M. M., Uddin, M. M., Hassan, M. M., Faridahsan, M. (2012): Fertility and hatchability of Fayoumi and Sonali chicks. - Scholarly J. Agric. Sci. 2: 83-86.

[27] Grashorn, M., Juergens, A., Bessei, W. (2016): Effects of storage conditions on egg quality. - Lohman Information 50(1). 
[28] Monira, K. N., Salahuddin, M., Miah, G. (2003): Effect of breed and holding period on egg quality characteristics of chicken. - Int. J. Poult. Sci. 2: 261-263.

[29] Mustafa, M. M., Al-Sardary, S. Y. (2009): Effect of broiler breeder age and short egg storage period on hatching trait and broiler performance. - M.Sc. Thesis, University of Duhok.

[30] Narushin, V. G., Romanov, M. N. (2002): Egg physical characteristics and hatchability. World's Poult. Sci. J. 58: 297-303.

[31] Nowaczewski, S., Witkiewicz, K., Kontecka, H., Krystianiak, S., Rosiński, A. (2010): Eggs weight of Japanese quail vs. eggs quality after storage time and hatchability results. - Archiv. Tierzucht. 53: 720-730.

[32] Peebles, E. D., Gardner, C. W., Brake, J., Benton, C. E., Bruzual, J. J., Gerard, P. D. (2000): Albumen height and yolk and embryo compositions in broiler hatching eggs during incubation. - Poult. Sci. 79: 1373-1377.

[33] Peebles, E. D., Doyle, S. M., Zumwalt, C. D., Gerard, P. D., Latour, M. A., Boyle, C. R., Smith, T. W. (2001): Breeder age influences embryogenesis in broiler hatching eggs. Poult. Sci. 80: 272-277.

[34] Reijrink, D., Berghmans, R., Kemp Meijerof, B., van den Brand, H. (2010): Influence of egg storage time and preincubation warming profile on embryonic development, hatchability, and chick quality. - Poultry Sci. 89: 1225-1238.

[35] Reijrink, I. A. M., Meijerhof, R., Kemp, B., van den Brand, H. (2008): The chicken embryo and its micro environment during egg storage and early incubation. - World's Poult. Sci. J. 64: 581- 598.

[36] Reijrink, I. A. M., Meijehof, R., Kemp, B., Graat, E. A. M., Van den Brand, H. (2009): Influence of prestorage incubation on embryonic development, hatchability, and chick quality. - Poult. Sci. 88: 2649-2660.

[37] Santos, M. S. V. (2005): Avaliação do desempenho e qualidade dos ovos de poedeiras comerciais, submetidas às dietas suplementadas com diferentes óleos vegetais. - Tese (Doutorado em Zootecnia), Universidade Federal do Ceará, Fortaleza.

[38] Sebastian, N., Mateusz, B., Sebastian, K. (2016): Effect of broiler breeders' age on eggshell temperature, embryo viability and hatchability parameters. - Ann. Anim. Sci. 16(1): 235-243.

[39] Silversides, F. G., Scott, T. A. (2001): Effect of storage and layer age on quality of eggs from two lines of hens. - Poult. Sci. 80: 1240-1245.

[40] Suk, Y. O., Park, C. (2001): Effect of breed and age of hens on the yolk to albumen ratio in two different genetic stocks. - Poultry Science 80: 855-858.

[41] Tilki, M., Saatci, M. (2004): Effects of storage time on external and internal characteristics in partridge (Alectoris graeca) eggs. - Revue Méd. Vét. 155: 561-564.

[42] Tona, K., Bamelis, F., Coucke, W., Bruggeman, V., Decuypere, E. (2001): Relationship between broiler breeder's age and egg weight loss and embryonic mortality during incubation in largescale conditions. - J. Appl. Poult. Res. 10: 221-227.

[43] Tona, K., Bamelis, F., De Ketelaere, B., Bruggeman, V., Moraes, V. M. B., Buyse, J., Onagbesan, O., Decuypere, E. (2003): Effects of egg storage time on spread of hatch, chick quality, and chick juvenile growth. - Poult. Sci. 82: 736-741.

[44] Tona, K., Onagbesan, O., Ketelaere, B., De Decuypere, E., Bruggeman, V. (2004): Effects of age of broiler breeders and egg storage on egg quality, hatchability, chick quality, chick weight, and chick post-hatch growth to forty-two days. - J. Appl. Poult. Res. 13: 10-18.

[45] Ulmer, A. M., Fasenko, G. M., Dea, E. E. (2010): Hatching egg characteristics, chick quality, and broiler performance at 2 breeder flock ages and from 3 egg weights. - Poul. Sci. 89: 2735-2742.

[46] Vieira, S. L., Almeida, J. G., Lima, A. R., Conde, O. R. A., Olmos, A. R. (2005): Hatching distribution of eggs varying in weight and breeder age. - Braz. J. Poultry Sci. 7(2): 73-78. 
[47] Yassin, H., Velthuis, A. G. J., Boerjan, M., van Riel, J., Huirne, R. B. M. (2008): Field study on broiler eggs hatchability. - Poult. Sci. 87: 2408-2417.

[48] Yeasmin, A., Azhar, K., Hishamuddin, O., Awis, Q. S. (2014): Effect of storage time and temperature on the quality characteristics of chicken eggs. - Journal of Food, Agriculture \& Environment 12(3-4): 87-92.

[49] Yildirim, I. E. (2005): Effects of breeder age and pre-incubation storage of eggs on hatchability, time of hatch and relative organ weight of quail chicks at hatch. - S. Afr. J. Anim. Sci. 35(2): 135-142.

[50] Zakaria, A. H., Plumstead, P. W., Romero-Sanchez, H., Leksrisompong, N., Brake, J. (2009): The effects of oviposition time on egg weight loss during storage and incubation, fertility, and hatchability of broiler hatching eggs. - Poultry Sci. 88: 2712-2717. 